\title{
INJURIES CAUSED BY Frankliniella spp. (THYSANOPTERA: THRIPIDAE) ON SEEDLESS GRAPES
}

\author{
Injúrias ocasionadas por Frankliniella spp. (Thysanoptera: Thripidae) em uva sem semente
}

\author{
Andréa Nunes Moreira ${ }^{1}$, José Vargas de Oliveira², José Eudes de Morais Oliveira ${ }^{3}$, \\ Geisa Mayana Miranda de Souza ${ }^{4}$, Mariana Oliveira Breda ${ }^{5}$
}

\begin{abstract}
Thrips of the genus Frankliniella cause significant reduction on grape production. Little is known about its decision making approach in integrated pest management and information on thrips injuries to the vine is scarce, hindering the control of this pest. This study aimed to determine the species of thrips and injuries that cause damage to berries in seedless grapes clusters. The trial was conducted in an area cultivated with Vitis vinifera L., variety Thompson Seedless, using a randomized block design with five treatments and four replications. The treatments consisted of artificial infestation (zero, two, four and eight thrips per inflorescence), and treatment determined by the monitoring system of the grower. Each replication consisted of three plants with 10 inflorescences, which were artificially infested with thrips and covered with nonwoven fabric bags. During the cluster thinning, pre-harvest cleaning and harvest, the numbers of injuried berries and the berries with injuries were evaluated. The thrips species identified were: Frankliniella schultzei (Trybom), Frankliniella brevicaulis Hood, Frankliniella gemina Bagnall, Frankliniella gardeniae Moulton, and Frankliniella sp. A positive and significant correlation was observed between the number of injuries per fruit and the level of thrips infestation, obtained by the equation $\mathrm{y}=2.55+48.54 \mathrm{x}\left(\mathrm{F}=59.98 ; \mathrm{P}=0.0001 ; \mathrm{r}^{2}=0.51\right)$. The results suggest that the presence of a whitish halo around a small scar on fruit is associated with the presence of adult Frankliniella spp.
\end{abstract}

Index terms: Vitis vinifera, thrips, integrated pest management, infestation level, damages.

\begin{abstract}
RESUMO
Os tripes do gênero Frankliniella ocasionam perdas consideráveis à produção da videira. Informações sobre os danos ocasionados por esses insetos e a tomada de decisão em programas de manejo integrado em videira são escassos, dificultando o controle dessa praga. Neste trabalho, objetivou-se determinar as injúrias e as espécies de tripes que ocasionam danos em bagas de uva sem semente. O experimento foi conduzido em área comercial de Vitis vinifera L, cultivar Thompsom Seedless, em blocos ao acaso, com cinco tratamentos e quatro repetições. Os tratamentos foram: 0, 2, 4 e 8 tripes por inflorescência e o nível de controle do produtor determinado pelo monitoramento da área. Cada repetição foi constituída de três plantas com 10 inflorescências cada, as quais foram infestadas com tripes adultos e cobertas com saco de TNT ${ }^{\mathrm{TM}}$ (tecido não tecido). Durante o raleio, limpeza pré-colheita e colheita foram avaliados: o número de injúrias nas bagas e o número de bagas com injúrias. As espécies identificadas foram: Frankliniella schultzei (Trybom), Frankliniella brevicaulis Hood, Frankliniella gemina Bagnall, Frankliniella gardeniae Moulton e Frankliniella sp. Obteve-se correlação positiva e significativa entre o número de injúrias nas bagas e o nível de infestação de tripes: $\left(\mathrm{y}=2,55+48,54 \mathrm{x} \quad\left(\mathrm{F}=59,98 ; \mathrm{P}=0,0001 ; \mathrm{r}^{2}=0,51\right)\right.$. Os resultados sugerem que a presença de um halo esbranquiçado ao redor de uma pequena cicatriz, presente nas bagas, está associada à presença de adultos de Frankliniella spp.
\end{abstract}

Termos para indexação: Vitis vinifera, tripes, manejo integrado de pragas, nível de infestação, danos.

\section{INTRODUCTION}

Thrips are considered a major pest of the common grape vine (Vitis vinifera L.) (Roditakis; Roditakis, 2007), being the genus Frankliniella one of the most important on various countries (McNally et al., 1985; Lopes et al., 2002; Tsitsipis et al., 2003; Mujica et al., 2007; Borbón, 2013).

In Brazil, Frankliniella occidentalis (Pergande) (Lopes et al., 2002), F. schultzei (Trybom) (Monteiro;
Mound; Zucchi, 2001; Monteiro, 2002), F. rodeos Moulton, synonym of $F$. gemina Bagnall (Cavalleri; Mound, 2012), F. gardeniae Moulton (Botton et al., 2007), F. brevicaulis Hood and an unidentified species of Frankliniella sp. (Moreira et al., 2012) were observed during the flowering of the grape vine.

Decision making and information on thrips injuries to the vine is scarce, hindering the control of this pest. In addition, thrips injuries to the berries are difficult to be

${ }^{1}$ Instituto Federal do Sertão Pernambucano/IF Sertão PE - Campus Petrolina Zona Rural - Laboratório de Produção Vegetal - Petrolina PE - Brasil andrea.nunes@ifsertao-pe.edu.br

2Universidade Federal Rural de Pernambuco/UFRPE - Departamento de Agronomia - Pernambuco - PE - Brasil

${ }^{3}$ Empresa Brasileira de Pesquisa Agropecuária/Embrapa - Laboratório de Entomologia - Petrolina - Pernambuco - PE - Brasil

${ }^{4}$ Universidade Federal da Paraíba/UFPB - Centro de Ciências Agrárias - Paraíba - PB - Brasil

5Universidade Federal Rural de Pernambuco/UFRPE - Entomoligia Agrícola - Pernambuco - PE - Brasil

Received in december 23, 2013 and approved in june 13, 2014

Ciênc. Agrotec., Lavras, v.38, n.4, p.328-334, jul./ago., 2014 
identified by the grower. Some authors (Jensen; Flaherthy; Luvise, 1981; Botton et al., 2007; Mujica et al., 2007) reported the presence of a whitish halo around a small scar at the place of posture, on the berries. Lopes et al. (2002) described a dark and suberized scar, in some cases causing Niagara grapes to crack and seeds to prolapse. These insects can cause other types of injuries, depending on crop and thrips species. In strawberry plants, F. occidentalis causes injuries in the stamens and floral receptacle, causing tanning on the surface of green and ripe fruit, without leading to deformations (Nondillo et al., 2010). In nectarine trees, this species was reported to cause tanning on the fruit surface and bark deformations (Pearsall, 2000; Tommasini; Ceredi, 2007). Pseudophilothrips sp. causes lesions in guava fruit, which can lead to fungal infections (Picanço et al., 2003). In bunches of bananas, Elixothrips brevisetis (Bagnall) causes rusting on the fruit peel (Lima; Milanez, 2013).

The objective of this study was to determine the injuries caused by different species of thrips in seedless grapes, grown in the Submédio do Vale do São Francisco region, in order to obtain subsidies for the establishment of economic injury level.

\section{MATERIALS AND METHODS}

The study was conducted from May to September 2010, in a commercial vineyard located in Casa Nova, Bahia, Brazil $\left(09^{\circ} 15^{\prime} 48.7^{\prime \prime} \mathrm{S}\right.$ and $\left.40^{\circ} 54^{\prime} 38.1^{\prime \prime} \mathrm{W}\right)$. The vines ( $V$. vinifera variety Thompson Seedless) were five years old and the growing area covered 5.2 ha, with 2.5 m x 3.5 m spacing.

A randomized block design with five treatments corresponding to infestation levels of zero (control), two, four and eight thrips per inflorescence and treatment applied by the grower, who relied on monitoring the area using as action level $20 \%$ of inflorescences infested with two or more thrips (Haji et al., 2001). During the experiment, this level reached $60 \%$ of inflorescences infested, which is equivalent to 12 or more thrips per inflorescence.

The replications were three successive plants, and 10 inflorescences per plant. At 22 days from pruning, each inflorescence was infested with adult thrips from the field and with no specific age established. The thrips were separated manually by using a stereomicroscope, packed in gelatinous capsules and released in nonwoven fabric bags (34.4 cm length, $15.4 \mathrm{~cm}$ width at the closed end, 28.3 $\mathrm{cm}$ at the open end). The bags containing the number of thrips corresponding to each infestation level were placed involving the inflorescences, attached with flexible wire to the peduncle or to the branch, to prevent the escape of insects. The treatment without thrips (control) was also bagged. Thrips samples were kept in the Laboratory of Entomology at Embrapa Semiárido.

After nine days of infestation, the treatments were opened and the inflorescences sprayed with fungicide and the growth regulator gibberellic acid, afterwards being closed again to avoid reinfestation. The bags were definitively removed for cluster thinning, 43 days after pruning. The discarded material was collected in a white plastic tray, weighted, counted and the number of injuries was determined. This procedure was carried out at preharvest cleaning and harvest, 114 days after pruning. The treatment by the grower included two insecticide applications for thrips control during flowering (at 26 and 33 days after pruning) and one more application of gibberellic regulator.

The number of injuries and thrips infestation were compared through the linear regression model $(y=2.55$ $\left.+48.54 \mathrm{x} ; \mathrm{r}^{2}=0.51\right)$. The means, standard errors and regression were calculated through the PROC MEANS PROC REG by SAS (SAS Institute 2001). The numbers of injuries in berries and berries with injuries, as well as the percentage of damaged berries, were calculated through analysis of variance and the Tukey's test at 5\% significance by the software SAS. The original data for the average percentage of injuries per number of berries were transformed into square root $(\mathrm{x}+0.5)$.

\section{RESULTS AND DISCUSSION}

The thrips species identified on grape vine inflorescences were: Frankliniella schultzei, F. brevicaulis, F. gemina, F. gardeniae and Frankliniella sp. The treatment applied by the grower presented the largest numbers of injuries per berry and berries with injuries, differing from the thrips-infested treatments, at cluster thinning $(0.19 \pm 0.01$; $0.06 \pm 0.01)$ and harvest $(0.05 \pm 0.01 ; 0.04 \pm 0.01)$ (Table 1). During the pre-harvest cleaning, the number of injuries and berries with injuries showed no significant differences, with means of $0.01 \pm 0.00\left(\mathrm{~F}_{4.55}=1.02 ; \mathrm{P}=0.4048\right)$ and 0.01 $\pm 0.00\left(\mathrm{~F}_{4,55}=0.99 ; \mathrm{P}=0.4195\right)$, respectively.

The average percentage of berries with injuries, in relation to the total number of berries discarded during cluster thinning and pre-harvest cleaning, was higher in the treatment by the grower $(7.0 \%)$, differing from the treatments with eight, four, two and zero thrips $(2.7,1.7$, 2.3 and $0 \%$, respectively) (Table 2 ). The same result was found at harvest, with $3.7 \%$ of berries damaged from the treatment by the grower (Table 2). This result shows that the higher the thrips infestation is, the greater is the number of berries discarded at cluster thinning and pre-harvest cleaning, as well as berries with injuries at harvest. 
Table 1 - Means $( \pm \mathrm{SE})^{1}$ of the number of injuries per berry and number of berries with injuries at cluster thinning, pre-harvest cleaning and harvest of Thompson Seedlees grapes, subject to different levels of thrips infestation. Casa Nova, BA.

\begin{tabular}{ccccccc}
\hline & \multicolumn{2}{c}{ Cluster thinning } & \multicolumn{2}{c}{ Pre-harvest cleaning } & \multicolumn{2}{c}{ Harvest } \\
\cline { 2 - 6 } Infestation levels & $\begin{array}{c}\text { Number of } \\
\text { injuries per } \\
\text { berry }\end{array}$ & $\begin{array}{c}\text { Number of } \\
\text { berries with } \\
\text { injuries }\end{array}$ & $\begin{array}{c}\text { Number of } \\
\text { injuries per } \\
\text { berry }\end{array}$ & $\begin{array}{c}\text { Number of } \\
\text { berries with } \\
\text { injuries }\end{array}$ & $\begin{array}{c}\text { Number of } \\
\text { injuries per } \\
\text { berry }\end{array}$ & $\begin{array}{c}\text { Number of } \\
\text { berries with } \\
\text { injuries }\end{array}$ \\
\hline 0 & $0.00 \pm 0.00 \mathrm{~b}$ & $0.0 \pm 0.00 \mathrm{~b}$ & $0.00 \pm 0.00 \mathrm{a}$ & $0.00 \pm 0.00 \mathrm{a}$ & $0.00 \pm 0.00 \mathrm{~b}$ & $0.00 \pm 0.00 \mathrm{~b}$ \\
2 & $0.02 \pm 0.01 \mathrm{~b}$ & $0.02 \pm 0.00 \mathrm{~b}$ & $0.00 \pm 0.00 \mathrm{a}$ & $0.00 \pm 0.00 \mathrm{a}$ & $0.01 \pm 0.00 \mathrm{~b}$ & $0.01 \pm 0.00 \mathrm{~b}$ \\
4 & $0.02 \pm 0.00 \mathrm{~b}$ & $0.01 \pm 0.00 \mathrm{~b}$ & $0.01 \pm 0.01 \mathrm{a}$ & $0.02 \pm 0.01 \mathrm{a}$ & $0.01 \pm 0.00 \mathrm{~b}$ & $0.01 \pm 0.00 \mathrm{~b}$ \\
8 & $0.02 \pm 0.01 \mathrm{~b}$ & $0.02 \pm 0.01 \mathrm{~b}$ & $0.20 \pm 0.19 \mathrm{a}$ & $0.01 \pm 0.00 \mathrm{a}$ & $0.01 \pm 0.00 \mathrm{~b}$ & $0.01 \pm 0.00 \mathrm{~b}$ \\
12 or more & $0.09 \pm 0.01 \mathrm{a}$ & $0.06 \pm 0.01 \mathrm{a}$ & $0.01 \pm 0.00 \mathrm{a}$ & $0.01 \pm 0.00 \mathrm{a}$ & $0.05 \pm 0.01 \mathrm{a}$ & $0.04 \pm 0.01 \mathrm{a}$ \\
\hline Statistics: F; P & $23.75 ; 0.0001$ & $11.68 ; 0.0001$ & $0.99 ; 0.4195$ & $1.02 ; 0.4048$ & $26.91 ; 0.0001$ & $26.37 ; 0.0001$ \\
\hline
\end{tabular}

${ }^{1}$ Means followed by the same letter, in the column, do not differ by the Tukey's test $(\mathrm{P}>0.05)$.

Table 2 - Means $( \pm \mathrm{SE})^{1}$ of the percentage of injuries, number of injuries per berries and number of berries with injuries at cluster thinning, pre-harvest cleaning and harvested of Thompson Seedless grapes, subject to different levels of thrips infestation. Casa Nova, BA.

\begin{tabular}{ccc}
\hline Infestation levels & $\begin{array}{c}\text { Percentage of injuries in the discarded berries at } \\
\text { cluster thinning + pre-harvest cleaning }\end{array}$ & $\begin{array}{c}\text { Percentage of injuries in the harvested } \\
\text { berries }\end{array}$ \\
\hline 0 & $0.0 \pm 0.0 \mathrm{a}$ & $0.0 \pm 0.0 \mathrm{a}$ \\
2 & $2.3 \pm 0.4 \mathrm{~b}$ & $0.8 \pm 0.1 \mathrm{~b}$ \\
4 & $1.7 \pm 0.4 \mathrm{~b}$ & $0.6 \pm 0.1 \mathrm{~b}$ \\
8 & $2.7 \pm 0.5 \mathrm{~b}$ & $0.9 \pm 0.1 \mathrm{~b}$ \\
12 or more & $7.0 \pm 0.7 \mathrm{c}$ & $3.7 \pm 0.4 \mathrm{c}$ \\
\hline Statistics: F; P & $32.62 ; 0.001$ & $73.10 ; 0.001$ \\
\hline
\end{tabular}

${ }^{1}$ Means followed by the same letter, in the column, do not differ by the Tukey's test $(\mathrm{P}>0.05)$.

The number of injuries in berries and the thrips infestation levels showed a significant correlation characterized by the equation $\mathrm{y}=2.55+48.54 \mathrm{x}\left(\mathrm{r}^{2}=\right.$ $0.51 ; \mathrm{F}=59.98 ; \mathrm{P}=0.0001$ ) (Figure 1). Some authors (Shipp; Wang; Binns, 2000; Wang; Shipp, 2001; HongHyun; Joon-Ho; Ki-Baik, 2007; Tommasini; Ceredi, 2007; Funderburk, 2009; Reisig; Godfrey; Marcum, 2009) have also observed a relationship between thrips damage and intensity of infestation in other crops. In nectarine buds, a positive and significant relationship was observed between the density of $F$. occidentallis larvae and fruit damage $\left(r^{2}=0.529 ; \mathrm{P}=0.02\right)$ (Pearsall, 2000).

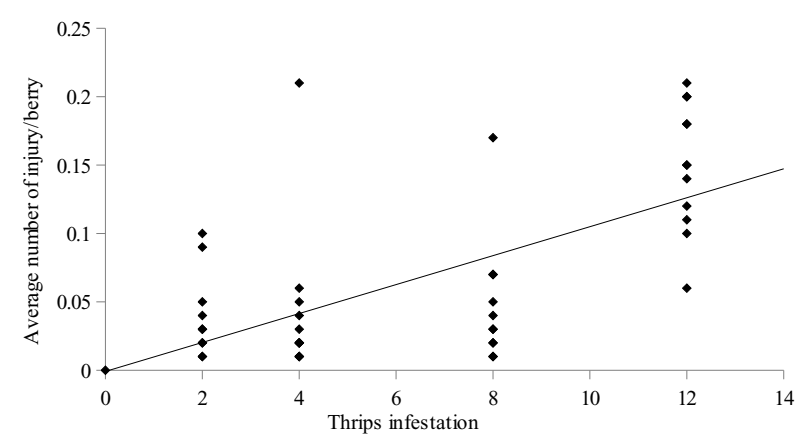

Figure 1 - Estimates of the number of injuries in Thompson Seedless grape berries, as a function of different levels of thrips infestation. Casa Nova, BA. 
As a damaged table grape berry is discarded during cluster thinning, pre-harvest cleaning and harvest, the infestation of two adults thrips per inflorescence (Tables 1 and 2) is sufficient to cause the loss of a berry. This is related to the elimination of damaged berries that compromise the cluster's quality, including visible damages caused by insects, due to high market standards (Lima, 2009).

Espadas (2008) explains that eggs placed on the tender tissues of berries in formation and the fluids released by the female at the time of laying, in contact with oxygen, prevent the closure of the lesion, producing the disruption of cells, showing the whitish in the berry tissue. With the growth of the fruit, the skin tends to crack at the point of injury, facilitating the growth of rot in bunches. Jensen, Flaherthy and Luvise (1981), Ripa, Rodriguez and Vargas (1993), Botton et al. (2007) and Mujica et al. (2007) observed similar injuries. In this research, the fruits at young berries $(>2 \mathrm{~mm})$ phase showed more visible injuries than those at harvest, probably due to their green coloration. Damaged berries frequently had a single scar; however, up to six scars were found on a single berry.
Other injuries caused by several thrips species have also been observed in grape berries. F. occidentalis produced dark and suberized scars on Niagara grapes, in some cases also causing the cracking of the berries and the prolapse of the seeds (Lopes et al., 2002). In mature clusters, $F$. occidentalis can cause browning around the contact area of berries or around the insertion of the stalk of the bunch (Espadas, 2008). Drepanothrips reuteri (Uzel) caused linear-shaped tanned stains, and $F$. occidentalis caused ring-shaped stains on ripe berries of Thompson Seedless (Roditakis; Roditakis, 2007). This variation is possibly related to the different thrips species that occur on the vine and the diversity of grape varieties. These symptoms were not observed in experimental vineyard during the study.

Starfish-shaped injuries were also observed (Figure 2C), corroborating previous studies about Thompson Seedless grapes (Jensen, 1973; Jensen; Flaherthy; Luvise, 1981; Ripa; Rodriguez; Vargas, 1993). In the present work, these scars were more evidenced on the clusters from the treatment by the grower, i.e., those that were not bagged. Probably, this injury results from the persistence of the
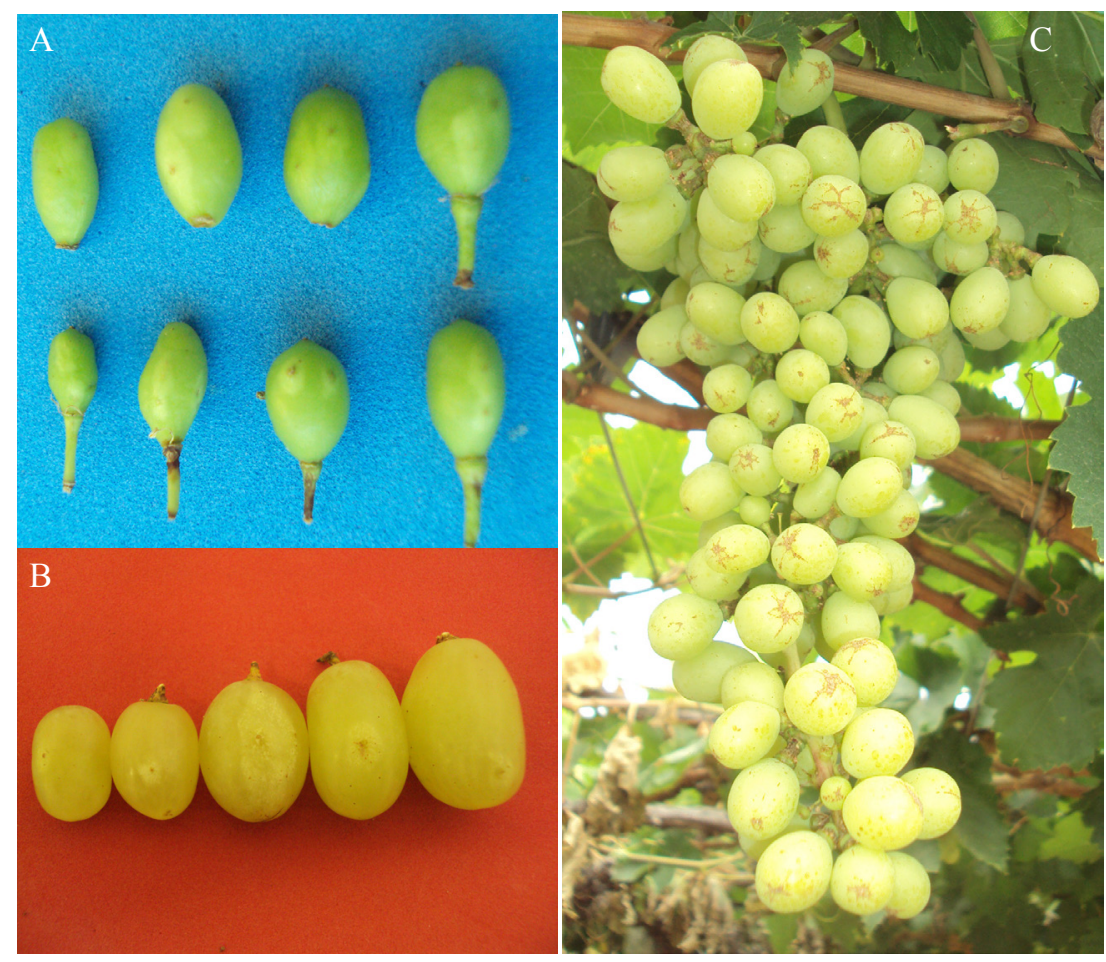

Figure 2 - Injuries in Thompson Seedless grape berries, Casa Nova, BA. A-Injuries caused by F. schultzei, F. brevicaulis, F. gemina, F. gardeniae and Frankliniella sp at the young berries phase. B-Injuries caused by F. schultzei, F. brevicaulis, F. gemina, F. gardeniae and Frankliniella sp. at harvest. C- Starfish-shaped scars. 
calyptra, which is fixed at the end or beside the berry, causing the scar. Gibberellic acid application at flowering can increase the number and visibility of these injuries, for stimulating cell growth. Jensen and Luvisi (1973) explained that this is associated to the flowering and fruiting time, and to the occurrence of lower temperatures. During the execution of the study, the temperatures were around $22^{\circ} \mathrm{C}$, which are considered mild ones for the semi-arid region. The other treatments, including the treatment without thrips, also showed these scars, but in reduced numbers. As the bagged clusters received one less application of gibberellic acid in the flowering period and were protected from the rain, this could have resulted in a smaller number of scars on berries.

According Jensen and Luvisi (1973) and Ripa, Rodriguez and Vargas (1993), these injuries are aggravated by the larvae of $F$. occidentalis sheltering in persistent calyptras of Thompson Seedless variety, however, experiments conducted by these authors do not explain the appearance of these scars in treatments without the presence of these insects. Thrips larvae can cause injuries when they feed mainly on pollen and stigma tissues of the calyptra, causing tanning tissue (Ripa, Rodriguez; Espinoza, 2001). However, hitherto, similar symptoms were not found in grape clusters infested or not by thrips larvae in warm seasons or other grape cultivars in the Submédio do Vale do São Francisco region (personal communication).

The results indicate that Frankliniella sp. causes an injury characterized by the presence of a whitish halo around a small scar on the berries. Thus, the information generated during this study can be useful to guide the decision making of the grower as to whether or not to control this thrips complex. Nevertheless, the possibility that other species of thrips may contribute to the occurrence of injuries cannot be excluded, therefore, it is important to continue to track and monitor these populations in grapevine in the Submédio do Vale do São Francisco region.

\section{CONCLUSIONS}

Levels of infestation of thrips (Frankliniella schultzei, F. brevicaulis, F. gemina, F. gardeniae and Frankliniella sp.), identified during the cluster thinning, pre-harvest cleaning and harvest of grapes, were positively and significantly correlatade with the number of injuries per fruit and the level of thrips infestation. The results suggest that the presence of a whitish halo around a small scar on fruits is due to the oviposition of thrips, associated with the presence of adult Frankliniella sp.

\section{ACKNOWLEDGEMENTS}

To UNIVEG Expofrut Brazil and Embrapa Semiárido for supporting this study. To Coordenação de Aperfeiçoamento de Pessoal de Nível Superior (CAPES) for granting a scholarship to Andréa N. Moreira. To Conselho Nacional de Desenvolvimento Científico e Tecnológico (CNPq) for the research productivity scholarships granted to Dr. José Vargas de Oliveira and Dr. José Eudes de Morais Oliveira. Dra. Renata C. Monteiro and Dr. Adriano Cavalleri for thrips identification.

\section{REFERENCES}

BORBÓN, C.M. de. Especies del género Frankliniella (Thysanoptera: Thripidae) registradas en la Argentina, una actualización. Revista de la Facultad de Ciencias Agrarias Universidad Nacional de Cuyo. 45(1):259284, 2013.

BOTTON, M. et al. Avaliação de inseticidas para o controle de Frankliniella rodeos (Moulton, 1933) (Thysanoptera: Thripidae) em uva de mesa no Brasil. Boletín de Sanidad Vegetal Plagas. 33(4):575-580, 2007.

CAVALLERI, A.; MOUND, L.A. Toward the identification of Frankliniella species in Brazil (Thysanoptera, Thripidae). Zootaxa. (3270):1-30, 2012.

ESPADAS, A.L. Plagas y Enfermedades de la Vid en la Región de Murcia. Murcia, Consejería de Agricultura y Agua Servicio de Sanidad Vegetal, 2008. 139p. (Formación Agoalimentaria, 15.)

FUNDERBURK, J. Management of the western flower thrips (Thysanoptera: Thripidae) in fruiting vegetables. Florida Entomologist. 92(1):1-6, 2009.

\section{HAJI, F.N.P. et al. Monitoramento de Pragas na} Cultura da Videira. Petrolina, Embrapa Semi-Árido, 2001. 29p. (Documentos 162).

HONG-HYUN, P.; JOON-HO, L.; KI-BAIK, U. Economic thresholds of western flower thrips (Thysanoptera: Thripidae) for unripe red pepper in greenhouse. Journal of Asia-Pacific Entomology. 10(1):45-53, 2007. 
JENSEN, F.L. Timimng of halo spotting by flower thrips on table grapes. California Agriculture Journal, v.27, n.10, p.6-8, 1973.

JENSEN, F.L.; FLAHERTHY, D.I.; LUVISE, D.A. Thrips. In: FLAHERTHY, D.L. (ed), Grape Pest Management. California, University of California, 1981. p.176-186.

JENSEN, F.; LUVISI, D. Flower thrips nynphs involved in scarring of Thompson Seedless grapes. California Agriculture.27(10):8-9, 1973.

LIMA, M.A.C. Fisiologia, tecnologia e manejo póscolheita. In SOARES, J.M.; LEÃO, P.C.S. (eds.), A Vitivinicultura no Semiárido brasileiro. Brasília, Embrapa Informação Tecnológica. Petrolina, Embrapa Semiárido, 2009. p. 597-656.

LIMA, EF; MILANEZ, J.M. Causing rusting on the fruit peel in several bunches of bananas. Neotropical Entomology.42(1):115-117, 2013.

LOPES, R.B. et al. Occurence of thrips on niagara table grape and its control with the insecticides thiacloprid and methiocarb associated with Metarhizium anisopliae. Revista Brasileira de Fruticultura. 24(1):269-272, 2002.

MCNALLY, P.S. et al. Effects of thrips (Thysanoptera: Thripidae) on shoot growth and berry maturity of "Chenin Blanc" grapes. Journal of Economic Entomology. 78(1):69-72, 1985.

MONTEIRO, R.C. The Thysanoptera fauna of Brasil, p. 325-340. In MARULLO, R.; MOUND, L.A. (eds.). Thrips and Tospoviruses: Proceedings of the 7th International Symposium on Thysanoptera, Canberra, Australian National Insect Collection, 2002. 379p.

MONTEIRO, R.C.; MOUND, L.A.; ZUCCHI, R.A. Espécies de Frankliniella (Thysanoptera: Thripidae) de importância agrícola no Brasil. Neotropical Entomology. 30(1):65-72, 2001.

MOREIRA, A.N. et al. Variação sazonal de espécies de tripes em videira de acordo com sistemas de manejo e fases fenológicas. Pesquisa Agropecuária Brasileira. 47(3):328-335, 2012.
MUJICA, M.V. et al. Fluctuación poblacional de Frankliniella occidentalis (Pergande) (Thysanoptera: Thripidae) en Vitis vinifera L. cv. Italia en la zona sur de Uruguay. Boletín de Sanidad Vegetal Plagas. 33(4):457-467, 2007.

NONDILLO, A. et al. Caracterização das injúrias causadas por Frankliniella occidentalis no morangueiro. Ciência Rural. 40(4):820-826, 2010.

PEARSALL, I.A. Damage to nectarines by the western flower thrips (Thysanoptera: Thripidae) in the interior of British Columbia, Canada. Journal of Economic Entomology. 93(4):1207-1215, 2000.

PICANÇO, M.C. et al. Dano, sistema de tomada de decisão, controle de Pseudophilothrips sp. (Thysanoptera: Phlaeothripidae) e sua relação com lesões fúngicas em frutos de goiaba. Acta Scientiarum Agronomy. 25(1):223-230, 2003.

RIPA, R.; RODRIGUEZ, F.; VARGAS, R. Asociacion entre trips (Thrips tabaci Lindeman y Frankliniella cestrum Moulton) durante la floracion en uva de mesa y "russet" en la cosecha. II. Aspectos biologicos.

Agricultura Tecnica. 53(1):16-22, 1993.

RIPA, R.; RODRIGUEZ, F.; ESPINOZA, F. El trips de California en nectarinos y uva de mesa. Chile, Instituto de Investigaciones Agropecuarias, 2001. 100p. (Boletin INIA, 53).

REISIG, D.D.; GODFREY, L.D.; MARCUM, D.B. Thresholds, injury, and loss relationships for thrips in Phleum pratense (Poales: Poaceae). Environmental Entomology. 38(6):1737-1744, 2009.

RODITAKIS, E.; RODITAKIS, N.E. Assessment of the damage potential of three thrips species on white variety table grapes - In vitro experiments. Crop Protection. 26(4):476-483, 2007.

SAS Institute. SAS User`s Guide: Statistics version 8 for Windows. SAS Institute, Cary, North Carolina, 2001.

SHIPP, J.L.; WANG, K.; BINNS, M.R. Economic injury levels for western flower thrips (Thysanoptera:Thripidae) on greenhouse cucumber. Journal of Economic Entomology. 93(6):1732-1740, 2000. 
TOMMASINI, M.G.; CEREDI, G. Damages on nectarines by thrips in northern Italy: monitoring and control on late attacks. Bulletin of Insectology. 60(1):71-75, 2007.

TSITSIPIS, J.A. et al. A novel scarring symptom on seedless grapes in the Corinth region (Peloponnese, southern Greece) caused by the western flower thrips, Frankliniella occidentalis, and pest control tests. IOBC WPRS Bulletin. 26(8):259-263, 2003.

WANG, K.; SHIPP, J.L. Sequential sampling plans for western flower thrips (Thysanoptera: Thripidae) on greenhouse cucumbers. Journal of Economic Entomology. 94(2):579-585, 2001. 